\title{
Henri Bergson a analytická filosofie ${ }^{1}$
}

\author{
Pavel Arazim \\ Filozofický ústav \\ Akademie věd České Republiky \\ Jilská 1, 11000 Praha 1 \\ arazim@flu.cas.cz
}

Henri Bergson se za svého života těšil velké popularitě. Přes jistý ústup ze slávy jeho filosofie i v druhé polovině dvacátého století inspirovala např. Gillese Deleuze. Nicméně analytická filosofie Bergsonovi dosud mnoho pozornosti nevěnovala. Ačkoli na první pohled skutečně s analytickou filosofií nemá mnoho společného, najdeme $\mathrm{v}$ jeho díle některé myšlenky, které by si zasloužily, aby je analytická filosofie zhodnotila. Zaměříme se na Bergsonovo pojetí špatně položených otázek, které je v mnohém podobné pojetí logických pozitivistů. Dále navrhneme, v čem může spočívat jeho př́nos pro teorii pravidel a normativistickou teorii významu. Obě témata jsou zde především programaticky nastíněna, jejich hlubší rozpracování je úkol pro další práci.

Klíčová slova: vitalismus, otázka, význam, pohyb a dynamika, Bergson, Wittgenstein, Brandom

\section{Úvod}

Filosofie Henriho Bergsona (1859-1941) je obvykle chápána jako zcela cizí analytické tradici. Klasičtí analytičtí filosofové jako byl Bertrand $\mathrm{Ru}-$ ssell nebo členové Vídeňského kroužku vůči některým svým filosofickým současníkům velmi ostře vystupovali. Známá je např. Carnapova polemika s Martinem Heideggerem, který pro mnoho analytických filosofü platil za ukázkový př́klad filosofa, jehož filosofie nedává dobrý smysl. ${ }^{2}$

1 Tento článek byl podpořen z grantu 17-15645S Logické modely usuzování a argumentace $v$ přirozeném jazyce vedeného Jaroslavem Peregrinem z Filozofického ústavu Akademie věd ČR.

2 Viz Carnap (1931). 
Podobně již Frege polemizoval s Husserlem o povaze matematického poznání. Husserlova a Heideggerova filosofie tedy přes veškeré rozdíly s analytickou filosofií nějakým způsobem přišla do styku, jejich myšlenky byly analytickými filosofy reflektovány, byt’ primárně ostře polemicky. Filosofie dvacátého století je často dělena na analytickou a tzv. kontinentální, do níž jsou počítáni např. právě Husserl a Heidegger. ${ }^{3}$ Henri Bergson by podle tohoto dělení byl jistě řazen mezi kontinentální filosofy, ovšem navzdory mimořádné popularitě, které se za svého života těšil, mu analytičtí filosofové - na rozdíl od mnoha jiných kontinentálních autorů - mnoho pozornosti nevěnovali, a to ani té čistě negativní. ${ }^{4}$

Vidím prozatím minimálně dva ohledy, ve kterých by Bergson analytické filosofy měl zajímat více. První je více historický a týká se některých zásadních podobností mezi Bergsonem a klasickou analytickou filosofií. Jak Bergson, tak analytičtí filosofové, především logičtí pozitivisté, byli přesvědčeni, že je potřeba filosofii zásadním způsobem reformovat a zbavit některých špatně položených otázek. Druhý ohled navazuje na ten první a týká se současných diskusí o povaze významu. V této druhé části článku ovšem bude potřeba trochu vykročit z interpretace samotné Bergsonovy filosofie a pokusit se tuto filosofii v některých ohledech aktualizovat. Výsledkem bude bergsonovsky upravený inferencialismus.

\section{1 Špatně položená otázka}

Jak zdůrazňuje ve své bergsonovské monografii Gilles Deleuze ${ }^{5}$, Bergson byl přesvědčen o tom, že filosofové před ním si kladli mnoho špatných otázek. Tato koncepce patrně není zcela nová, přesto je na Bergsonovi poměrně unikátní, jak často a jak otevřeně se k ní hlásí. Jde totiž o tvrzení s paradoxním nádechem. Přinejmenším na první pohled je překvapivé, že by otázka mohla být špatně, protože obvykle otázka teprve určuje, co je dobře a co je špatně. Správná nebo špatná tedy může, řeklo by se,

3 Různé způsoby vzájemného potýkání se těchto dvou tradic jsou popsány v článku Tvrdý (2016), ovšem z perspektivy bližší spíše tradici analytické.

4 Ovšem zcela stranou pozornosti analytických filosofů Henri Bergson nezůstal. V již zmíněném článku Tvrdého (2016) se lze dočíst o Russelově kritice Bergsona, ale ta zůstala spíše izolovanou epizodou a navíc Russell své výhrady publikoval ještě v době, kdy se rozdělení filosofie na analytickou a kontinentální teprve rýsovalo na obzoru.

5 Viz Deleuze (1966). 
být pouze odpověd’. Bergson si ovšem všímá, že danou otázku lze obvykle položit pouze za určitých podmínek. Tuto skutečnost zjevně ilustruje např. klasická sofistická otázka Užjsi přestal bít svého otce?, která předpokládá, že dotazovaný se již na svém otci nějakého násilí dřive dopouštěl. Obecně tedy přinejmenším v určitých kontextech dává smysl ptát se, zda bylo správné položit danou otázku, možná měla být položena nějaká jiná, případně žádná. Ne vždy jsou ale tyto podmínky tak nasnadě jako $\mathrm{v}$ př́ípadě zmíněné otázky na bití otce, jejich odhalení může vyžadovat hlubší analýzu.

Předpokladu smysluplnosti otázky se běžně ř́ká presuposice. Bergson měl za to, že některé filosofické otázky se vyznačují tím, že stojí na presuposicích, které vycházejí z jistých problematických pojmů, se kterými jsme zvyklí pracovat, ale které nás $\mathrm{v}$ daném kontextu zavádějí do slepých uliček a vytvářejí neřešitelné problémy. $V$ tomto akcentu můžeme spatřovat jistou spřízněnost Henriho Bergsona s jeho analytickými současníky. Téma špatně položené otázky je jedním z leitmotivů filosofie Ludwiga Wittgensteina. Ale také v díle členů nebo přátel tzv. Vídeňského kroužku, jako byl např. Rudolf Carnap nebo Moritz Schlick ${ }^{6}$, najdeme mnoho zmínek o tom, že některé filosofické otázky jsou chybně položené. Nejde navíc pouze o historicky zajímavé téma, protože i dnešní analytická filosofie navazuje na tradici zkoumání legitimity filosofických otázek. Např. podle Rortyho je mnohé tradiční otázky lepší rozpustit (dissolve) nežli vyřešit (resolve), jak se snaží ukázat ve svém stěžejním díle Filosofie a zrcadlo př́rody. ${ }^{7}$

\subsection{Jak taková špatně položená otázka vznikne}

Podívejme se nyní podrobněji na to, proč podle Bergsona dochází $\mathrm{k}$ tomu, že ve filosofii máme sklon klást si neřešitelné otázky. Následně Bergsonovo pojetí porovnáme s tím, které přinesli analytičtí filosofové. Nejprve ale musíme stručně představit základy Bergsonovy filosofie.

Pokud chceme stručně charakterizovat Bergsonovo myšlení, můžeme je nejprve přiblížit konstatováním, že Bergson je filosof pohybu a dy-

6 Viz Carnap (1931), Schlick (1932), Wittgenstein (1922).

7 Rorty (1979). 
namiky. Realita a do ní zasazený lidský subjekt se vyznačují především tím, že jsou dynamické, ale přesto máme silný sklon realitu pojímat jako něco statického. Typickým projevem této tendence je naše orientace na věci spíše než na děje. Samozřejmě počítáme s tím, že věci jsou v pohybu a mění se, ale pohyb i změnu chápeme jako něco sekundárního. Nejprve tady máme věci a až poté se s nimi eventuálně něco děje. Bergsonovi tento přístup, ač je nepochybně přirozený, připadá jednostranný a vede podle něj právě $\mathrm{k}$ tomu, že se dostáváme do zajetí špatně položených a nakonec neřešitelných otázek.

Typickým projevem této fixace na to, co je statické, a upozad’ováním pohybu, jsou např. Zenónovy paradoxy. Z původního fenoménu při nich jednostranné pojetí odstraňuje to nejpodstatnější, totiž pohyb. Zaměňujeme jej pak za pouhou trajektorii, kterou dané těleso, at’ už letící šíp nebo Achilleus a želva, prošlo. Potom se stává nejasným, jak mohl šíp někam doletět nebo jak mohl Achilleus v závodě želvu předběhnout. Přitom je jasné, že se to běžně děje, takže máme na výběr ze dvou nepřijatelných odpovědí - nemůžeme říci ani to, že Achilleus želvu předběhne, ani opak. Každá z variant je ovšem nepřijatelná jinak, můžeme říci, že jedna je nepřijatelná z teoretických, zatímco druhá z faktických důvodů.

Ignorování dynamických aspektů reality často vede $\mathrm{k}$ tomu, že se na ni díváme optikou stavi̊, jimiž prochází. Ptáme se, zda se nachází spíše ve stavu A nebo ve stavu B. Pokud se ale realita mezi těmito dvěma stavy pohybuje, není př́liš plodné chtít rozhodnout, ve kterém stavu právě je. Přitom nejde ani tak o to, že by podle Bergsona byla realita typicky někde mezi stavem A a stavem B v jakémsi mezistavu. I to by bylo pro něj zkreslující chápání, vlastně pouhá variace na zjednodušující myšlení, které má být překonáno. Stále bychom popírali právě to pro Bergsona nejpodstatnější, totiž pohyb, a nechávali ho rozplynout v jeho rozmanitých fázích.

Na začátku spisu Vývoj tvořivý ${ }^{8}$ Bergson konstatuje, že tato statická optika také pokřivuje náš pohled na vlastní mysl a nakonec celkově na

8 Bergson (1907, s. 11): „Il est commode de ne pas faire attention à ce changement ininterrompu, et de ne le remarquer que lorsqu'il devient assez gros pour imprimer au corps une nouvelle attitude, à l'attention une direction nouvelle. A ce moment précis on trouve qu'on a changé d'état. La vérité est qu'on change sans cesse, et que l'état lui même est déjà du changement.“ [Můj překlad: „Je pohodlné nevěnovat pozornost této neustálé proměně a nevšimnout si jí, dokud se nestane dostatečně velkou, aby tělu vtiskla nový postoj, pozornosti nový směr. Přesně v takové chvíli máme za to, že se stav změnil. Ve skutečnosti probíhá změna neustále a samotný stav je již změnou."] 
nás samotné. Fixace na to, co je stálé, nás vede $\mathrm{k}$ tomu, abychom se na vlastní mysl dívali prizmatem stavů, jimiž prochází. Přitom se zdá, že po dobu, kdy je mysl v daném stavu - ku příkladu zrovna přemýšlíme o Bergsonovi - je naše mysl stálá. Když ale kterémukoli stavu naší mysli věnujeme větší pozornost, musíme podle Bergsona uznat, že tento stav v sobě nic stálého nemá, naopak je neustálým plynutím. Správně bychom tedy měli vidět právě toto plynutí mysli jako její základní charakteristiku a ve stavech spatřovat poněkud umělé abstrakce, které mohou být užitečné pro některé praktické účely. Problematice filosofie mysli se zde nebudeme blíže věnovat, ale je zjevné, že z Bergsonovy perspektivy se i v této oblasti mnoho obvyklých i dodnes aktuálních otázek bud’ rozplyne, nebo radikálně změní.

Každopádně se ještě musíme seznámit s Bergsonovým pojmem trvání (durée). Podle Bergsona všechny rozmanité druhy pokřiveného nahlížení na realitu, které vedou k nesmyslným otázkám, vycházejí z neadekvátního porozumění času. Bergson byl přesvědčen, že máme sklon nahlížet na čas pouze jako na další rozměr prostoru. Tento sklon jenom posiluje moderní fyzika, která je právě na takovém pojetí založená. Čas ale podle Bergsona má i další aspekty, které jej činí neredukovatelným na prostor ani na cokoli jiného. Čas nezbavený tohoto původního charakteru pak Bergson označuje právě jako zmíněné trvání. A jaký je tedy onen charakter trvání a toho, co trvá? Především zmíněná dynamičnost, nejasnost přechodů mezi jednotlivými věcmi. Obecně věci nejsou primárnější než děje. Dále také platí, že k trvání náleží radikální novost v trvání neustále vzniká něco nového a nepředvídatelného. Pokud od trvání odhlížíme, máme sklon realitu a jednotlivé fenomény homogenizovat, kvalitu redukovat na kvantitu a nové vidět jako pouhou variaci na to, co již známe. Tento přístup je sice praktický, ale přinejmenším v jistých zásadních kontextech zavádějící. ${ }^{9}$

9 Bergson osvětluje pojem trvání v rámci celého svého díla. Mluví o něm již ve svém prvním významném spisu Esej o bezprostředních datech vědomí, kde mu věnuje druhou kapitolu (viz Bergson, 1889). Ilustrativní je např. také tato pasáž z prvního eseje ze souboru Myšlení a pohyb (Bergson, 1934, s. 4): „,...couramment, quand nous parlons du temps, nous pensons à la mesure de la durée, et non pas à la durée même. Mais cette durée, que la science élimine, qu'il est difficile de concevoir et d'exprimer, on la sent et on la vit.“ Český překlad, s. 13: „... když mluvíme o čase, obvykle myslíme míru trvání, a nikoli trvání samo. Avšak toto trvání, které věda eliminuje, které je obtížné pochopit a vyjádřit, cítíme a žijeme.“ 


\subsection{Analytická filosofie a nesmyslné otázky}

Logičtí pozitivisté vidí jako hlavní zdroj špatně položených otázek špatně fungující jazyk. Uvidíme, že toto pojetí má mnoho společného s Bergsonem, ale také se od něj zásadně odlišuje. S mimořádnou jasností toto pozitivistické pojetí prezentuje Carnap v klasickém článku Vyvrácení metafyziky logickou analýzou jazyka. Carnap v podstatě rezervuje termín „metafyzika' právě pro to, co považuje za defektní filosofii. Typická metafyzická otázka se vyznačuje tím, že ve skutečnosti nedává dobrý smysl, a tudíž ani př́padné odpovědi na ni nemohou být smysluplné. Mohou se sice zdát zásadní a hluboké, ale ve skutečnosti nic neříkají, nejsou tedy pravdivé ani nepravdivé.

Nesmyslná věta obecně podle Carnapa vznikne bud' tak, že obsahuje bezobsažné slovo nebo se sice skládá výhradně ze smysluplných slov, ale ta jsou poskládána nekorektním způsobem, takže nakonec smysluplná věta přece jenom nevznikne. Jako př́ílad nesmyslného metafyzického slova Carnap uvádí princip. Původně toto slovo sice mělo jasný význam, nebo možná více jasných významů. Mohlo jednoduše znamenat počátek něčeho v čase. Metafyzikové ale toto slovo používají ve větách jako Principem světa je číslo způsobem, který se tomuto původnímu významu i případným jiným podobným vymyká. Zdá se být hlubší, ale ve skutečnosti je bezobsažné. ${ }^{10}$ Jako př́klad věty, která se skládá pouze ze smysluplných slov, ale celkově smysluplná není (a tedy to nakonec vlastně ani není věta, ale pouhá pseudověta), Carnap uvádí Caesar je a. Je jasné, že věta nemůže končit spojkou $a$. Nesmyslnost této věty lze ihned nahlédnout, ale na metafyzice je podle Carnapa záludné právě to, že je plná pseudovět, jejichž nesmyslnost je mnohem hưře patrná. Např. Heideggerovo Nic nicuje se podle Carnapovy diagnózy proti smysluplnosti prohřešuje oběma uvedenými způsoby, a to sice použitím nesmyslného slovesa nicovat a postavením slova nic do pozice podmětu. ${ }^{11}$

Jak může Carnap - a s ním další logičtí pozitivisté - obecně poznat, že daná věta postrádá smysl? Umožňuje mu to jeho striktní a kontroverzní chápání toho, v čem význam spočívá. Význam dané věty spočívá

\footnotetext{
10 Carnap (1931, s. 225).

11 Viz Carnap (1931, s. 229).
} 
v metodě její empirické verifikace. Jednotlivé věty pak můžeme pomocí logických konstrukcí jako je např. konjunkce, disjunkce, implikace, kvantifikace apod. spojovat do vět složených. Vedlejším produktem toho, že naše jazyky disponují tímto logickým aparátem, je existence tautologií a kontradikcí, tedy vět, které jsou z logických důvodů bud' vždy pravdivé, nebo vždy nepravdivé. Smysluplná věta tedy musí být bud’ tautologie, kontradikce nebo u ní musí být jasné podmínky empirické verifikace. Metafyzické věty nezapadají ani do jedné z těchto kategorií, a tudíž jsou nesmyslné. Pro úplnost můžeme dodat, že ačkoli metafyzické věty nic netvrdí, mohou vyjadřovat jakýsi životní pocit autora a podobně naladěných lidí. Proto jsou pro leckoho také tak přitažlivé. Nicméně zpravidla podle Carnapa nejsou pro vyjádření pocitu zdaleka tak vhodné jako umění. Hlavní problém ale je v tom, že na rozdíl od umění ze sebe metafyzika dělá něco, čím není, totiž oblast jakýchsi hlubokých poznatků.

Odhalování smyslu dané věty je podle logických pozitivistů možné díky moderní logice. Teprve ona umožňuje dostatečně jasnou analýzu, která mimo jiné dokáže odhalit nesmyslnost zdánlivě hlubokých metafyzických výroků. Pokud by měla být metafyzika královská disciplína, pak moderní logika ukazuje, že král je nahý, respektive královna je nahá.

\subsection{Srovnání obou pojetí}

Jaké tedy nacházíme podobnosti a jaké rozdíly v Bergsonově pojetí nesmyslných otázek a v pojetí logických pozitivistů? A v čem může být jejich srovnání přínosné? Na první pohled je vidět, že Bergson není tak radikální jako logičtí pozitivisté, když hovoří pouze o špatně položených, nikoli o nesmyslných otázkách. Může jít z větší části o pouze rétorický rozdíl, nicméně Bergsonovo pojetí zjevně více otevírá dveře $\mathrm{k}$ pochopení toho, jak dané otázky vznikají. Podle logických pozitivistů jde vlastně o neštastnou historickou náhodu a těchto otázek je potřeba se jednou provždy zbavit, ač to může být poměrně komplikované. Bergsonovo pojetí se naopak o něco více podobá Kantovu, podle kterého tkví náš sklon klást si neřešitelné otázky v samotné struktuře našeho rozumu. Bergsonovo vysvětlení je ale více pragmatistické. 
Podle Bergsona si musíme uvědomit především to, jakou funkci náš rozum primárně má. $V$ první řadě napomáhá naší činnosti, nikoli nezaujatému poznání. V zásadě je funkcí rozumu umět předvídat vývoj okolního světa a plánovat naše adekvátní reakce na tento vývoj. Proto si všímáme spíše toho, co se v okolním světě opakuje, odhlížíme od jedinečnosti daného fenoménu a díváme se na něj jako na exemplár̆ nějakého obecného druhu, který je způsoben fenoménem jiného druhu a zase jiný sám způsobuje. Tento př́ístup je z hlediska našeho praktického obstarávání zcela legitimní a velmi přínosný, ale podle Bergsona nás zavádí na scestí, pokud se jím necháme př́liš vést i ve filosofické spekulaci. Přehližíme pak původní trvání, ve kterém není jasných rozdílů mezi jednotlivými entitami a realita tvoří kontinuální dynamický celek. Co z hlediska analýzy vypadá jako velmi složitá struktura, to je z hlediska skutečného děje jednoduché, a tudíž musí být běžným způsobem neanalyzovatelné. Pak ale máme sklon zaměňovat praktickou a teoretickou perspektivu a hledat solidní a stabilní věci tam, kde vládne spíše plynulost a dynamika.

V Bergsonově pojetí tedy falešné filosofické otázky vznikají velmi přirozeně a podobně jako Kant by mohl i Bergson konstatovat, že se podobají optickým klamům. Ačkoli můžeme vysvětlit, že jde o klamy, stále máme sklon vidět některé věci zavádějícím způsobem, a proto máme také tendenci k chybným úsudkům. Jistě lze tento sklon klást si falešné otázky mírnit, ale těžko jej můžeme z bergsonovské perspektivy chtít vymýtit.

Další výrazný rozdíl mezi Bergsonem a logickými pozitivisty spočívá v tom, jak kdo chápe roli jazyka a logiky při vzniku špatně položených otázek. Na první pohled jsou jejich př́stupy zcela opačné. Logičtí pozitivisté spatřují v logice nástroj, který umožňuje po staletích tápání spolehlivě rozlišit mezi dobře a špatně položenými otázkami. Teprve moderní fregovská logika umožňuje jasně určit logickou formu daného výroku a tím stanovit, co skutečně ř́ká, pokud vůbec něco. Dosud filosofii podle analytické ortodoxie chyběla dostatečná jasnost v analýze pojmového aparátu, který používá, a proto také $\mathrm{v}$ mnoha případech nebylo možné nahlédnout, že zdánlivě hluboké problémy jsou ve skutečnosti pseudoproblémy. Henri Bergson se o logice a s ní zároveň o jazyce vyja- 
dřuje, jak uvidíme v následující kapitole, ne příliš lichotivě a vidí v nich naopak původce těch nejškodlivějších klamných otázek.

Na druhou stranu se Bergson se svými analytickými současníky v podstatě shoduje na základních cílech, totiž na reformě filosofie, která ji nasměruje směrem k smysluplnějším otázkám. Když se snaží diagnostikovat, co dosavadní filosofii chybělo, vyjádří se v podstatě jako logický pozitivista. Soubor esejů a přednášek Myšlení a pohyb uvádí konstatováním, že filosofii dosud chyběla především přesnost. Přesnost ovšem chápal jako těsné přiléhání filosofie ke skutečnosti, tedy konkrétnost. ${ }^{12}$ Jak přesně se liší logicko-pozitivistické a Bergsonovo pojetí by, mělo být jasnější, když se podíváme na to, jak Bergson nahlížel na logiku a obecně na jazyk.

\section{Role logiky}

Bez jazyka bychom si ovšem žádné otázky klást nemohli, at' už dobré nebo špatné. Co tedy konkrétně podle Bergsona logika, případně jazyk dělají? Především je nutno hned na začátku podotknout, že podobně jako Bergsonova filosofie nebyla př́liš reflektována jeho analytickými současníky ani dalšími generacemi analytických filosofü, ani samotný Bergson nevěnoval mnoho pozornosti moderní logice. Změny, kterých logika díky Fregovi a dalším doznala, Bergson podle všeho bud' nezaznamenal, nebo mu nepřišly zásadní.

Lze se ale dohadovat, že svůj pohled považoval za aplikovatelný na logiku starou stejně jako na novou. Obecně podle Bergsona logika a jazyk slouží jako nástroje pro upevňování tekuté a dynamické reality. Mají sklon vytvářet jasné distinkce a dichotomie a nahrazovat jimi plynulé přechody mezi jednotlivostmi. Díky logice máme sklon obecně chápat svět kolem nás jako složený z věcí, které mají své vlastnosti. Bergson opakovaně zdůrazňuje, že toto porcování reality má svůj praktický význam a je do velké míry legitimní, ale přesto nás ochuzuje o přístup $\mathrm{k}$ hlubším

12 Viz Bergson (1934, s. 1): „Ce qui a le plus manqué à la philosophie, c'est la précision. Les systèmes philosophiques ne sont pas taillés à la mesure de la réalité où nous vivons. Ils sont trop larges pour elle.“ Český překlad, s. 11: „Nic dosud nechybělo filosofii tolik jako přesnost. Filosofické systémy nejsou střiženy na míru skutečnosti, v níž žijeme. Jsou na ni př́liš velké.“ 
vrstvám reality a zkušenosti. Především nám zakrývá dynamickou a živou realitu, odvádí nás od ní pouze $k$ tomu, co je statické a neživé. ${ }^{13}$

Jasněji strukturovanou realitu můžeme spíše adekvátně vyjádřit a poté také sdílet. Podle Bergsona ale můžeme pomocí specifické intuice poznávat i původnější, dynamičtější vrstvy reality. Takové poznání je ale obecně špatně formulovatelné, každá formulace přináší určité rozparcelování reality a popírá skutečnou dynamiku. Nepostihuje pak realitu nejenom v její dynamičnosti, ale také v její konkrétnosti. Není tedy v Bergsonově smyslu přesná.

Logičtí pozitivisté a už samotný Frege se ostatně o roli logiky vyjadřují dosti podobně. Podle nich má skutečně sloužit $k$ tomu, abychom mohli dělat jasná rozlišení a pracovat s jasně vymezenými pojmy. Teprve tak můžeme podle nich dosahovat skutečně platného poznání. Je ovšem třeba poznamenat, že tito autoři plně uznávají, že v běžném životě nám nejde o teoretické poznání, a tudíž v běžné konverzaci nemusejí být naše pojmy opravdu důsledně vymezeny. Ve vědě, která je podle nich jediným zdrojem skutečného poznání, se ale bez této důslednosti neobejdeme. Frege tento postoj hezky ilustroval, když vztah svého Begriffschriftu (jak doufal, zárodku budoucího jazyka přísné vědy) a přirozeného jazyka přirovnal ke vztahu mikroskopu a pouhého oka. Mikroskop nám velmi dobře poslouží, pokud chceme svět kolem sebe vidět skutečně detailně a přesně, na druhou stranu právě pro svou přesnost je nepoužitelný v běžném životě. $\mathrm{V}$ obvyklých situacích funguje naše prosté oko velmi dobře, stejně jako přirozený jazyk, a těžko je něco může nahradit. ${ }^{14}$

Na rozdíl od Bergsona logičtí pozitivisté ani Frege neuznávají, že by mohlo existovat nějaké poznání, které je silně individualistické v tom smyslu, že by nebylo přistupné vyjádření ve sdíleném jazyce. Viděli jsme tedy, že Bergson i klasičtí analytičtí filosofové chtěli přinést do filosofie

13 Bergson své chápání logiky a její role postupně osvětluje např́č svým dílem. Někdy mluví o $o b$ vyklé logice (logique habituelle - viz Bergson (1934, s. 20, respektive s. 27 v českém překladu), aby naznačil, že může existovat i jiná logika, která realitu tímto způsobem nezjednodušuje. Pro představu dobře poslouží také tento citát ze začátku spisu Vývoj tvořivý (Bergson, 1907, s. i): „... notre logique est surtout la logique des solides, que, par là même, notre intelligence triomphe dans la géométrie, où se révèle la parenté de la pensée logique avec la matière inerte... “ [Můj překlad: „...naše logika je především logikou pevných těles, a tím pádem naše inteligence triumfuje v geometrii, v níž se odhaluje spřízněnost logického myšlení a inertní hmoty..."]

14 Frege (1879, s. v). 
více přesnosti, ale zároveň je vidět, že onou přesností Bergson rozuměl něco jiného. Zatímco analytičtí filosofové chtěli především jasnost, jednoznačnost a také empirickou testovatelnost, Bergson hledal co nejpřesnější vystižení konkrétní žité reality. $\mathrm{K}$ přesnosti logických pozitivistů tedy patři pokud možno úplné odpoutání se od čehokoli subjektivního. Na druhé straně Bergson chce proniknout do skutečnosti tak, jak ji žijeme, takže to vypadá, že chce postihnout prožitek v jeho konkrétnosti, a tedy nejspíše také subjektivitě.

Zdá se tedy, že se bergsonovské a raně analytické pojetí přesnosti nakonec přes podobná východiska vylučují. Jejich vztah by si ovšem zasloužil ještě hlubší analýzu, která by tento závěr mohla přece jenom zpochybnit. Důležité by bylo podívat se blíže na pojem zkušenosti u logických pozitivistů a také vzít v potaz, že Bergson měl nejspíše za to, že intuitivní poznání dynamických vrstev reality do velké míry překračuje i distinkci mezi subjektivním a objektivním. Nicméně Bergson byl také přesvědčen, že jazykové vyjádření takovéto hlubší poznání musí deformovat, byt’ se tuto deformaci můžeme snažit co nejvíce zmírnit. Takže sice také často hovoří o problémech spojených s použiváním málo projasněných pojmů, ale zjevně s logickými pozitivisty nesdílel ideál dokonale projasněného jazyka. Př́liš mnoho projasňování nakonec vede $\mathrm{k}$ popření podstatných rysů reality, a tím pádem nakonec paradoxně k novému druhu nejasnosti.

\subsection{Logický expresivismus a jeho meze}

Nyní je vhodné zaměřit se na jedno specifické rozvinutí Fregova a klasického analytického pojetí logické analýzy, totiž na inferencialismus a logický expresivismus, jak je vypracoval Robert Brandom ${ }^{15}$. Podle Brandomova pojetí slouží logika $\mathrm{k}$ tomu, aby vyjadřovala pravidla vyvozování. Tuto myšlenku dále rozvíjí a hegelovsky ř́ká, že logika je nástrojem sémantického sebevědomí. Podle Brandoma totiž pravidla vyvozování konstituují význam našich výrazů a na jeho základě také naše myšlení.

Brandomova doktrína předpokládá, že pravidlo má nějakou specifickou podobu a tu můžeme díky logice vyjádřit. Až následně je možné dané pravidlo případně změnit, protože když je již vyjádřeno, může se stát

15 Především viz Brandom (1994). 
předmětem diskuse, $v$ jejímž rámci zvažujeme důvody pro toto pravidlo a proti němu. Mám ale za to, že v tomto př́padě jde o př́lišné objektivizování pravidla, Brandom se na ně dívá př́liš moc jako na věc a málo jako na proces a pohyb. Můžeme tedy Brandomovo pojetí zkusit podrobit kritice z (novo-)bergsonovských pozic.

Brandom ovšem sám poskytuje určitá vodítka pro nuancovanější pojetí toho, jak pravidla fungují a co s nimi logika dělá. Především zdo̊razňuje, že některá pravidla musejí být v daném kontextu implicitní. Představa stavu, kdy by všechna pravidla byla vyjádřena, nedává dobrý smysl. Jednak by takové vyjádření pravidel znamenalo, že budou zcela vysvětleny všechny významy $\mathrm{v}$ daném jazyce, což by muselo vést ke kruhu ve vysvětlení. Za druhé Wittgenstein ukázal ve Filosofických zkoumáních ${ }^{16}$, že každé pravidlo může být $\mathrm{v}$ jistých kontextech nejasné a každé případné dovysvětlení je nutno interpretovat, přičemž se musíme řídit pravidly pro interpretaci tohoto dovysvětlení, a ta opět nebudou zcela explicitní.

Skutečnost, že nikdy nejsou všechna inferenční pravidla explicitní, otevírá možnost, že toho o pravidlech víme méně, než by se zdálo. Dalším východiskem nám může být Brandomovo pojetí toho, co dané pravidlo konstituuje. Podle Brandoma spočívají pravidla v našich normativních postojích. Dané pravidlo tedy zjednodušeně řečeno platí, pokud je nějaké jednání považováno v dané komunitě za správné a jiné za nesprávné. Ve skutečnosti to samožrejmě bude složitější, pravidlo může platit za jistých podmínek i tehdy, když je většina společnosti odmítá, pokud je prosazuje někdo, kdo poživá autority. $V$ zásadě je ale podstata pravidel takto jednoduchá. Normativní sféra tedy navazuje na sféru nenormativní, na naše přirozené chování v rámci skupin, které vytváříme. ${ }^{17}$ $\mathrm{Z}$ toho hlediska tedy můžeme dát smysl Wittgensteinovu vyjádření, že pravidla musejí být založena na sdílené formě života členů dané komunity. ${ }^{18}$ Musíme vykazovat jistou uniformitu v tom, jak jednáme a jak na

16 Viz Wittgenstein (1953, především §§ 80-81).

17 Plnohodnotná sociální skupina je pak ovšem možná až v kontextu určitých sdílených norem, a tedy po ustanovení jisté normativní sféry. Daná životní forma pak nemusí být neměnná a od normativity izolovaná, naopak se bude se vznikajícími pravidly vzájemně prolínat. Ovšem zde hovořím právě o fázi, kdy sociální skupiny a s nimi i pravidla teprve vznikají.

18 Wittgenstein hovoří o formě života např. ve Wittgenstein (1953, § 241). 
sebe navzájem reagujeme, a na tomto základě se konstituuje rozdělování jednání na z různých hledisek správné a nesprávné.

Jako přiblížení toho, v čem taková forma života spočívá, bychom mohli použít právě Bergsonovo pojetí života. Na první pohled to sice vypadá, že Wittgensteinovi jde pouze o jistou míru uniformity v našem chování, která zakládá normativitu. Nicméně k životnosti dané formy života patří také to, že se neustále vyvíjí. Jednotlivá pravidla i celé systémy pravidel, které jsou v životní formě ukotveny, proto musíme také pochopit jako živoucí a dynamické. Jednotícím prvkem je kontinuita vývoje a ne jeho dílčí výsledky. Podobně v Bergsonově analýze fyzického pohybu platí, že není možné postihnout podstatu tohoto pohybu, když ho budeme chtít rekonstruovat z dílčích zastávek. Rozdíl mezi pohybem a klidem je absolutní a skládáním klidných částí nedostaneme pohyblivý celek. Dynamickou povahu pravidel si ostatně uvědomoval sám Wittgenstein, který ve svém spise O jistotě mluvil o tom, že věty, které patří k obrazu našeho světa, se mohou v různých kontextech stávat jak pevnějšími a stálejšími, tak naopak pohyblivějšími. Ilustroval to kontrastováním řeky a jejího koryta. ${ }^{19}$

Pravidlo a soubor pravidel je tedy třeba nahlédnout jako pohyb, a to v radikálním smyslu. Můžeme toto pojetí kontrastovat se dvěma statičtějšími. Nejstatičtější pojetí ztotožňuje pravidlo s nějakou jeho konkrétní podobou. Jakmile dojde $\mathrm{k}$ nějaké změně v daném pravidle, musíme podle tohoto pojetí hovořit o novém, jiném pravidle, i když možná podobném tomu původnímu. Toto pojetí ignoruje vývoj, kterému podléhají jazyk jako celek a obecně naše pravidla, a je z tohoto hlediska nanejvýš statické. Podle tohoto pojetí se může systém daných pravidel vyvíjet nanejvýš tím, že se některá stará pravidla vymění za nová. Příkladem je změna pravidel přijímacích zkoušek na vysokou školu - stále jde o stejný systém pravidel, který se už ovšem skládá z jiných jednotlivých pravidel.

Určitý krok vpřed již představuje pojetí, podle kterého se může totéž pravidlo vyvíjet a během vývoje měnit svou podobu. Takové pojetí je

19 Viz Wittgenstein (1984, § 96): „Man könnte sich vorstellen, dass gewisse Sätze von der Form der Erfahrungssätze erstarrt wären und als Leitung für die nicht erstarrten, flüssigen Erfahrungssätze funktionierten; und daß sich dies Verhältnis mit der Zeit änderte, indem flüssige Sätze erstarrten und feste flüssig würden.“ Český překlad: „Mohli bychom si představit, že určité věty, které mají formu zkušenostních vět, by ztuhly a fungovaly by jako vodítko pro neztuhlé, tekuté zkušenostní věty; a že by se časem tento poměr měnil, takže tekuté věty by ztuhly a pevné věty by se staly tekutými.“ 
již více bergsonovské, ale stále pravidlo ztotožňuje s jeho různými podobami, jenom připouští, že se tyto podoby mohou měnit. Jako pokrok je ale možno vidět již to, že se nerozlišuje mezi vývojem jednotlivého pravidla a nějakého systému pravidel, jehož je dané pravidlo součástí. Již toto pojetí je pro mnoho analytických filosofů kontroverzní, ale není jasné, proč by mělo potřebovat více obhajoby než předchozí statičtější pojetí.

Podle mě ale původ pravidel $\mathrm{v}$ dynamické formě života postihne až pojetí, které jde dále a jako primární chápe právě pohyb pravidel. Vývoj již není chápán jako něco, co se pravidlu může, ale také nemusí přihodit, ale jako jeho podstata. Takové chápání pravidel sice Bergson přímo neformuluje, ale domnívám se, že jde o plausibilní aplikaci jeho filosofie na sféru pravidel a normativity.

Zdá se, že když Bergson popisuje dynamickou realitu trvání, hovoří o něčem, co má s pravidly málo společného. Na základě jeho uvedených vyjádření na adresu logiky bychom se dokonce mohli domnívat, že pro Bergsona musí pravidla náležet právě do statické sféry času, který byl redukován na další rozměr prostoru. Ve své poslední knize Dva zdroje morálky a náboženstuí se ovšem Bergson tématu normativity dotýká a hovoří o tom, jak se morálka a náboženství potřebují obnovovat a opět nabývat životního elánu. Morálka a náboženství nás podle Bergsona nevedou $\mathrm{k}$ následování pouze silou nátlaku, ale také silou aspirace. ${ }^{20} \mathrm{Za}-$ tímco první síla vede k upevňování již existujícího morálního nebo náboženského řádu, ta druhá na něj sice navazuje, ale zároveň jej překračuje. Pokud pochopíme morálku a náboženství jako mimo jiné soubory pravidel, nabízí se tento motiv z Bergsonova posledního spisu aplikovat na normativitu obecně a osvětlit tak dynamičnost pravidel. Vztah mezi silou nátlaku a silou aspirace také připomíná Wittgensteinovu zmíněnou metaforu o řece o jejím korytu. Bergson zde podobně jako Wittgenstein tematizuje vztah méně pohyblivé sféry a dění, pro které vytváří podmín-

20 Bergson (1932, s. 53): „Dans la prèmiere, l'obligation represente la pression que les éléments de la société exercent les uns sur les autres pour maintenir la forme du tout ... Dans la seconde, il y a encore obligation, si l'on veut, mais l'obligation est la force d'une aspiration ou d'un élan, de l'élan même qui a abouti à l'espèce humaine...“ [Můj překlad: „V prvním př́padě obligace představuje nátlak, který členové společnosti na sebe navzájem vyvíjejí, aby uchovali formu celku ... V druhém př́padě můžeme, pokud chceme, také hovořit o obligaci, ale tato obligace je silou aspirace nebo elánu, téhož elánu, který vývojově vyústil v člověka jako živočišný druh..."] 
ky, vlastně prostor. Toto dění ale onen prostor zároveň zpětně ovlivňuje.

Vrat’me se ale k naší kritice Brandomova logického expresivismu z Bergsonem inspirované perspektivy. Pravidlo je tedy především pohyb a systém pravidel je výslednice různých dílčích pohybo̊, dynamická stejně jako jeho části. $Z$ tohoto hlediska pak ale nelze př́ísně vzato mluvit o vyjádření daného pravidla. Pravidlo platí tehdy, když nastává určitá odpovídající konstelace normativních postojů v dané komunitě. Jak s ním pak ale souvisí jeho verbální vyjádření, tedy to, co je má podle Brandoma činit explicitním? Řekl bych, že spíše než jako na nástroj, kterým činíme explicitním to, jakou podobu dané pravidlo má, funguje toto vyjádření spíše jako nástroj k jeho modifikaci nebo usměrnění.

Z tohoto hlediska také není úplně štastná Brandomova terminologie, která dělí pravidla na explicitní a na ta - zatím - implicitní. Pravidlo může pouze platit, nebo neplatit v dané komunitě a to, že je vyjádřeno, ještě jeho platnost, jak by nejspíš sám Brandom uznal, nezaručuje. Na první pohled to asi působí zvláštně, je přece rozdíl mezi nepsaným pravidlem a zákonem, který je explicitně formulován a na jehož přesné formulaci velmi záleží při posuzování jednotlivých případů u soudu apod. Z naší perspektivy je ale tento rozdíl spíše pouze kvantitativní, i když nepochybně velký. Pravidla, která regulují zákony, jsou mimořádně stabilní, protože společnosti na jejich stabilitě záleží. Jiná pravidla jsou ovšem stabilní do velké míry sama od sebe, nap̌r. etické pravidlo, že vražda je špatná, nebo matematické pravidlo, že dva a dva jsou čtyři. Nicméně i tato pravidla nejsou zcela nehybná, ačkoli kontexty, kdy by jejich zpochybňování mohlo dávat dobrý smysl, jsou nanejvýš vzácné.

Celkově ale můžeme z bergsonovského hlediska vyslovit diagnózu, že Brandom při svém pojetí pravidel př́liš podléhá statické racionalitě, a tudíž pravidla vytrhuje z jejich původního trvání a zasazuje je pouze do prostoru a do času, který je na prostor redukovaný. Nicméně jako Bergson obecně uznává, že tento druh racionality je důležitý, podobně lze konstatovat, že Brandomovo chápání pravidel jako něčeho pevného, co můžeme učinit explicitním, je užitečné a v jistém smyslu nezbytné pro naše praktické fungování. Ovšem z filosofického hlediska je přínosné přijmout i (novo-)bergsonovskou perspektivu, podle které i pravidla trvají. 


\subsection{Bergsonovský inferencialismus a logický expresivismus?}

Navržené pojetí normativity chápu jako modifikaci Brandomova inferencialismu a logického expresivismu v bergsonovském duchu. Mělo by být poměrně jasné, $v$ jakém ohledu se toto pojetí odchyluje od samotného Brandoma a snad i od analytické filosofie obecně. Je ale nasnadě otázka, nakolik je toto pojetí věrné samotnému Bergsonovi.

Bergson, jak jsme již viděli, obvykle chápe logiku a jazyk jako nástroje redukce času na prostor a $\mathrm{s}$ tím obecně redukci dynamické reality na statická schémata. Styku s původní dynamickou realitou přitom podle Bergsona dosahujeme především jako jednotlivci. Mimo jiné se musíme odpoutat od vlivu, který na nás má společnost. A protože pravidla chápeme jako zásadně společenská a obecná, vypadá to, že podle Bergsona musí být původnímu trvání cizí.

Já ovšem navrhuji Bergsonovo pojetí reality, která se děje v trvání, rozššririt i na sféru normativity a pravidel, včetně pravidel logiky a jazyka. Jistě není divu, že si Bergson nevybral tuto sféru pro ilustraci toho, jak rozumí trvání. Lze dokonce říci, že tato sféra je jakýsi protipól sféry plynutí mysli, fyzického pohybu a pohybu obecně. Přesto považuji za poměrně neproblematické dovedení Bergsonovy filosofie do důsledku, když řekneme, že nějakým způsobem musejí trvat i pravidla, kterými se řídíme. Podobně jako se Bergson snažil změnit naše běžné chápání pohybu, můžeme takto změnit i naše chápání pravidel a hodnot. Pokusil jsem se ilustrovat, že Bergson tímto směrem sám vykročil ve svém posledním díle Dva zdroje morálky a náboženstuí.

Nicméně nepovažuji co nejdoslovnější věrnost Bergsonově filosofii za hlavní hodnotu. Pokud mé pojetí vykračuje z jeho filosofie směrem, který sám Bergson naznačuje, pak $\mathrm{v}$ tom vidím bergsonovský př́stup $\mathrm{k}$ samotnému Bergsonovi. Připomínám, že má modifikace Brandoma také vychází z motivů, které jsou v něm samotném (a ve Wittgensteinovi) př́tomné, byt’ možná spíše implicitně. $V$ tomto ohledu je předložené pojetí také brandomovské. 


\subsection{Pragmatistická linie}

Poté, co jsem se v první části zaměřil na výklad myšlenek samotného Bergsona, ve druhé části jsem si dovolil jeho myšlenky jistým, podle mě nenásilným, způsobem aktualizovat. Tuto aktualizaci lze ospravedlnit a dodat jí další obsah, když zohledníme Bergsonův vztah k pragmatismu. Bergsonovými současníky byli totiž kromě raných analytických filosofů také klasičtí pragmatisté. Bergsona jejich filosofie přitom oslovovala a především s Williamem Jamesem si projevovali vzájemnou úctu a osobní i filosofické sympatie. ${ }^{21}$

Přitom poté, co byl pragmatismus zastíněn především klasickou analytickou filosofí reprezentovanou Bertrandem Russellem a logickými pozitivisty, v druhé polovině dvacátého století jej analytičtí filosofové stále více do svého vlastního myšlení integrují, a tak mu dávají nový život. Také Brandom má k pragmatismu blízko. $Z$ tohoto hlediska lze Bergsonem inspirovaný posun inferencialismu chápat také jako další způsob, jak pragmatismus aktualizovat a v nové podobě nabídnout současné debatě. Snad to lze pochopit i jako způsob, jak pragmatické motivy v inferencialismu dovést do jejich důsledků. Vztah Bergsona a klasického i novějšího pragmatismu je nepochybně také téma, které by se mělo hlouběji prozkoumat.

\section{Závěr}

Pokusil jsem se alespoň zběžně naznačit několik linií, po kterých by se mohla ubírat reflexe díla Henriho Bergsona v rámci analytické filosofie. V mnoha ohledech si lze od Bergsona především odnést zajímavé srovnání s tím, čím se analytická filosofie (nebo přinejmenším některé její proudy) vyznačuje. Takovéto srovnání může napomoci analytické filosofii vidět, čím je ona sama specifická a případně podnítit sebereflexi. Kromě toho jsme ale $\mathrm{v}$ př́padě problematiky pravidel měli možnost vidět, že Bergson může být do některých proudů v rámci analytické filosofie integrován a napomoci jejich dalšímu rozvoji.

21 Bergson Jamesovi např. věnuje předposlední z esejů ve sbírce Myšlení a pohyb, viz Bergson (1934). 


\section{Literatura}

Bergson, H. (1889): Essai sur les données immédiates de la conscience. Felix Alcan, Bibliothèque de philosophie contemporaine, Paris.

Bergson, H. (1907): L'Évolution créatrice. Felix Alcan, Bibliothèque de philosophie contemporaine, Paris.

Bergson, H. (1932): Les Deux Sources de la Morale et de la Religion.

Felix Alcan, Bibliothèque de philosophie contemporaine, Paris.

Bergson, H. (1934): La pensée et le mouvant. Essais et conférences.

Felix Alcan, Bibliothèque de philosophie contemporaine, Paris; český překlad (J. Čapek, J. Fulka, J. Hrdlička \& T. Chudý) Myšlení a pohyb, Mladá fronta, Praha, 2003.

Brandom, R. (1994): Making it Explicit. Harvard University Press, Cambridge.

Carnap, R. (1931): „Überwindung der Metaphysik durch logische Analyse der Sprache." Erkenntnis 2 (1): 219-241.

Deleuze, G. (1966): Le Bergsonisme. Presses Universitaires de France, Paris.

Frege, G. (1879): Begriffschrift. Nebert, Halle.

Rorty, R. (1979): Philosophy and the Mirror of Nature. Princeton University Press, Princeton.

Schlick, M. (1932): „The Future of Philosophy.“ In College of the Pacific Publications in Philosophy Vol 1, ed. P. A. Schilpp, College of the Pacific, Stockton, s. 45-62.

Tvrdý, F. (2016): „Střet kontinentální a analytické filosofie.“ Filosofie dnes 8 (2): 3-19.

Wittgenstein, L. (1922): Tractatus Logico-Philosophicus. Routledge Kegan Paul, London.

Wittgenstein, L. (1953): Philosophische Untersuchungen. Blackwell, Oxford.

Wittgenstein, L. (1984): Über Gewißheit. Suhrkamp, Frankfurt am Main; český překlad (V. Zátka) Ojistotě, Academia, Praha, 2010. 


\section{Abstract \\ Henri Bergson and analytical philosophy}

During his lifetime, Henri Bergson achieved great popularity. Despite a certain decline of the attention paid to his philosophy, his work kept inspiring authors even in the second half of twentieth century, among others Gilles Deleuze. Nevertheless, the analytical philosophy has rather ignored Bergson so far. Though at first sight his philosophy seems orthogonal with the analytical tradition, his work contains ideas which could prove productive for the analytical thought. We will focus on Bergson's approach to wrong questions which in many respects resembles that of logical positivists. Then we will propose how Bergson's ideas can contribute to the theory of rule-following and normativistic theories of meaning. Both issues will be rather just sketeched, a more detailed elaboration remains yet to be pursued as further work.

Klíčová slova: vitalism, question, meaning, movement and dynamics, Bergson, Wittgenstein, Brandom

Arazim, P. (2019): „Henri Bergson a analytická filosofie.“ Filosofie dnes 11 (1): 97-115. Dostupné z www.filosofiednes.ff.uhk.cz 